\title{
THE RIGHT TO DIE AND POWER OVER LIFE: KNOWLEDGE TO GOVERN THE BODIES ${ }^{1}$
}

\author{
Franciele Roberta Cordeiro², Maria Henriqueta Luce Kruse ${ }^{3}$
}

\begin{abstract}
${ }^{1}$ Paper elaborated based on the thesis - Do I decide on my end?: the media and the production of subjects who govern their death, presented to the Programa de Pós-Graduação em Enfermagem, Universidade Federal do Rio Grande do Sul (URGS), in 2013.

2 Doctoral student, Programa de Pós-Graduação em Enfermagem, UFRGS. Porto Alegre, Rio Grande do Sul, Brazil. E-mail: franciele. cordeiro@ufrgs.br

${ }^{3}$ Ph.D. in Education. Professor, Escola de Enfermagem, Programa de Pós-Graduação em Enfermagem, UFRGS. Porto Alegre, Rio Grande do Sul, Brazil. E-mail: kruse@uol.com.br
\end{abstract}

\begin{abstract}
This study aimed to examine how the media articulates the knowledge and positions involved in the process of death and dying. Documentary research in the field of post-structuralist cultural studies. The empirical material consisted of ten interviews, published in the magazines Época and Veja, between 2000 and 2012. To delimit the corpus of analysis, we used discursive mapping by means of the software ATLAS.ti. The findings were submitted to discourse analysis inspired by Foucault. In the reports, nursing appeared linked to care for the body and technical procedures, leading to the conclusion that the media constructs the professionals' image, according to the historical attributes linked to the professions. The knowledge of medicine and of justice is authorized to teach the subject to decide and to plan the death. Power/ knowledge relations are outlined that legitimize the discourse on the production of a singularized death, which must be provided by the subjects using an expert of health.
\end{abstract}

DESCRIPTORS: Nursing. Philosophy, nursing. Death. Culture.

\section{DIREITO DE MORTE E PODER SOBRE A VIDA: SABERES PARA O GOVERNO DOS CORPOS}

\begin{abstract}
RESUMO: O objetivo deste estudo foi analisar o modo como a mídia articula e posiciona os saberes envolvidos no processo de morte e morrer. Trata-se de uma pesquisa documental, inserida no campo dos estudos culturais, na vertente pós-estruturalista, cujo material empírico se constituiu em dez reportagens publicadas nas revistas Época e Veja, entre os anos 2000 e 2012. Para delimitar o corpus de análise, foi realizado um mapeamento discursivo pelo software ATLAS.ti, e os achados foram submetidos à análise do discurso de inspiração foucaultiana. Nas reportagens, a enfermagem apareceu atrelada aos cuidados com o corpo e com procedimentos técnicos, o que levou à conclusão de que a mídia constrói a imagem dos profissionais, conforme os atributos históricos ligados às profissões. Evidenciou-se que os saberes da medicina e jurídicos estão autorizados a ensinar os sujeitos a decidirem e planejarem a morte. São traçadas relações de poder/saber que legitimam os discursos sobre a produção de uma morte singularizada, a qual deve ser proporcionada pelos sujeitos, mediante um expert da saúde.
\end{abstract}

DESCRITORES: Enfermagem. Filosofia em enfermagem. Morte. Cultura.

\section{DERECHO DE MUERTE Y PODER ACERCA DE LA VIDA: SABERES PARA LO GOBIERNO DE LOS CUERPOS}

RESUMEN: Estudio que tuvo como objetivo examinar cómo la media articula y posiciona los saberes implicado en el proceso de muerte y morir. Investigación documental, se inscribe en el campo de los estudios culturales, en su vertiente Post-Estructuralista. El material empírico fueron diez reportajes publicados en las revistas Época y Veja, entre 2000 y 2012. Para organizar el corpus de análisis, se utilizó el software ATLAS.ti. Los resultados fueron sometidos al análisis del discurso de Foucault. La medicina y el jurídico están autorizados a enseñar sobre decisiones de la muerte. La enfermería está ligada al cuidado del cuerpo y los procedimientos técnicos. Se concluye que los medios construye la imagen del profesional con los atributos históricos de las profesiones. Las relaciones de poder/saber legitiman los discursos que producen una muerte singularizado que debe ser proporcionada por los sujetos y debajo de los experts de la salud.

DESCRIPTORES: Enfermería. Filosofía en enfermería. Muerte. Cultura. 


\section{INTRODUCTION}

Fear, joy, sadness, suffering, these are some of the feelings that emerge in relation to the end of life. Fear of dying. Joy for being together with the family. Sadness about the moment lived. Suffering because of the pain, the loss, the end. Today, death is no longer a solitary, macabre and sober event but part of daily life. This change mainly happened based on the movements observed throughout the $20^{\text {th }}$ and in the early $21^{\text {st }}$ century. To give an example, the international conventions are highlighted that inserted the notion of human rights in the political context, as well as the invention of palliative care as a care philosophy for the end of life and the creation of public policies and guidelines to promote a homebased process of dying, produced by the subjects. ${ }^{1-2}$

The power and knowledge relations surrounding death have changed in the past three centuries. In Brazil, mainly as from the year 2000, a series of discussions and investments emerged in programs and guidelines driven by the palliative care principles, whose main actors are not only the professionals, but also the patients, who are called upon to participate actively in the decisions about their health, disease and death. ${ }^{3}$ Some home care programs articulate knowledge areas that allow the subjects to govern whether they die in hospital or at home. The knowledge put in practice generally involves nursing, medicine, dentistry and psychology. More recently, through the encouragement of discussions about legislations related to death, the legal area has entered this context, legitimizing the subjects' will at the end of their life. Argentina, for example, was one of the first Latin countries to discuss the will of the dying subject. In May 2012, the country's Senate unanimously approved the law of a dignified death, which allows people to choose the conditions they want to die in. In Brazil, Resolution $1.995 / 2012$ was approved, which determines on advanced health care directives for cases of diseases beyond possibilities of cure. ${ }^{4}$

This reveals the importance of debating the production of death under the subjects' control with the health professionals' accompaniment. In that sense, the media serves as a pedagogical device that grants visibility to what is produced in terms of public policies. It produces and is produced by discourses intended to modify behaviors, habits and practices related to life and death. ${ }^{5}$ Thus, the media contributes to drive the subjects' behaviors through the truths that circulate based on the articulation of statistical calculations, probabilities and science. These elements enhance the production and organi- zation surrounding life and death, which summon and position knowledge the subjects should build on to support different kinds of decisions.

Hence, the media is identified as an important territory of tensions and production of modes of dying. Therefore, the following question is raised: how do Brazilian informative magazines outline and grant visibility to the professional territories in the context of the end of life? With a view to problematizing the theme through the historical and cultural perspectives, the objective in this study is to analyze how the media articulates and positions the knowledge involved in the process of death and dying.

\section{METHOD}

A qualitative documentary research was undertaken in the post-structuralist branch of cultural studies. The empirical material consisted of magazine reports on the dying process. Reports were retrieved that discussed death related to lifethreatening diseases. Hence, news on accidents, crimes and tragedies were discarded. The decision to work with magazines is justified by the varied public these artifacts are able to reach. The discourse was taken from two artifacts, both in the public domain and important in Brazil: Veja, by the publisher company Abril, and Época, by the publisher company Globo. On the whole, these magazines have a weekly print run of approximately one million and 500 thousand copies.

The magazine Veja runs weekly, with about one million copies. As its name suggests, the magazine calls upon its target public, Brazilian adults, to see and read news that circulates in Brazil and around the world. On its pages, a wide range of topics is discussed, such as politics, economics and technology. Launched in 1968, it is considered one of the largest magazines in the Brazilian context.

Issued by a large publisher company and affiliated with an important organization in the Brazilian social and political scenario (Organizações Globo), the mean print run of the magazine Época is 500 thousand copies. The magazine is issued weekly and discusses themes like sports, politics, economics, science, health and entertainment.

The search for the reports was undertaken in the virtual libraries and print copies of the journals between December 2012 and January 2013. The full reports were consulted, published as from the year 2000, when the movements started about the decisions regarding the end of life and care for patients with life-threatening diseases. In Brazil, as 
from the year 2000, Palliative Care services were implemented, the National Humanization Policy ${ }^{6}$ was published, as well as the National Cancer Care Policy, ${ }^{7}$ the National Home Care Policy ${ }^{8}$ in 2013 and, finally, in 2012, the approval of Resolution N. 1.996/12 on the elaboration of Advanced Directives of the Patients. ${ }^{4}$ These events are considered emerging surfaces of the transformation in the health care context. At the end of the survey, ten reports were included, four from Veja and six from Época, published between 2002 and 2012.

The titles of the reports included in the empirical material for the research are: "Até onde prolongar a vida [Extend life until where]" (Veja); "Em busca de um final sereno [In search of a serene ending]" (Veja); "A mulher que alimentava [The woman who fed]" (Época); "A enfermaria entre a vida e a morte [The nursing ward between life and death]" (Época); "A ética na vida e na morte [Ethics in life and death]" (Veja); "Testamento Vital [Vital Will]" (Época); “O filho possível [The possible child]" (Época); "Ajudame a morrer [Help me to die]" (Época); "Você quer ser pessoa ou paciente? [Do you want to be a person or a patient]" (Época) and "O direito de escolher [The right to choose]" (Veja).

The content of the reports is related to the conditions people die in. The journals question the therapeutic choices for the end of life, recommend on the elaboration of a vital will and assess the subjects' level of preparation to make decisions in critical health situations. Therefore, they particularly consult health and legal experts. Through the texts and images, a trajectory is outlined which people suffering from diseases beyond cure are to follow.

To delimit the analysis corpus, a discursive map of the reports was elaborated, using the free trial version of the qualitative data organization and analysis software ATLAS.ti 7, offered free of charge for evaluation. ${ }^{9}$ The research findings were submitted to discourse analysis in line with Michel Foucault. ${ }^{10-11}$ The notion of discourse was used as a methodological tool, and the notion of government as an analytic framework. This archeological analysis is related to an excavation process in search of the historical circumstances or contingencies that constitute a form of thinking and power relations. These relations produce knowledge, standards, rules and positivities. In other words, this means saying that the know-how operation, encouraged by discourse analysis, functions "as machinery, as a social machine that is not situated in a privileged or exclusive place, but is disseminated throughout the social structure". 12:14
Concerning the ethical aspects related to the use of images in this work, it is highlighted that they are part of the public domain, in accordance with Law N 9.610/1998. Its use is particularly based on the declarations in Article 46, chapter IV, Item I and III. ${ }^{13}$

\section{RESULTS AND DISCUSSIONS}

For the sake of the following analysis, the discourse about death in the magazines was considered, adopting the following criterion: "insistence, repetition and regularity"14:53 of the statements, focusing on the way the health professionals are positioned, based on their knowledge locations. The way was described in which the three main knowledge areas are displayed which the media articulates when discussing the end of life: Nursing, Medicine and Law. It is known that, in studies based on Foucault, there exists no linear conception of the historical facts. Hence, in this study, the visibilities of each knowledge area are appointed to facilitate the reader's understanding. In addition, images are used in the belief that they capture the perspective and make people think. They are an important resource the media uses to produce meanings that add up to the written text.

\section{(In)visibilities of Nursing in care for the dying}

Nursing appears discretely and restricted to the technical activities linked to the body and the procedures that help with symptom control. It is the most visible profession after medicine in the health care context. Historically, nursing and medicine stand out in the establishment of hospitals and in the conjuncture of care for the ill. They operative through hierarchies, both between and inside both professions. ${ }^{15}$ In the reports, the historical memory of nursing is displayed, linked to doing, to practice and to the disciplining of the body for care. ${ }^{16}$

"The reality of the patient's body was that appalling that Kathia Camargo, an experienced nurse, suffered to do the dressing". 17:62

"Maintaining a terminal patient is a decision that implies huge problems. When the symptoms get worse, relatives or hired nurses need to transform part of the house into a small hospital (our highlights)" ${ }^{18: 97}$

The above excerpts reveal the central role of nursing activities, of the way the professional works with the patients to minimize the health damage. It seems that care does not need a set of specific 
regulations, standards and laws as, according to the reports, relatives can perform it. These descriptions simplify the activities of Nursing professionals and, consequently, disqualify the profession towards dying subjects. A profession can be understood as a construct, based on a group of workers trained to perform activities and who "master the fundamentals for its accomplishment". 19:740 Thus, Nursing can be considered a knowledge area constituted beyond practice, which uses different sources of discourse to promote care and work in an ethical and coherent manner.

In its constitution, modern Nursing, particularly in Brazil, is inspired by a North American model, marked by the disciplining of the nurses' bodies. In their education, besides technical and scientific skills, they should present good interpersonal relationships and exemplary moral and professional conducts. Through this set of actions, the nurses professionalized care, turning it into an element beyond experience, an object resulting from systemized scientific intervention. ${ }^{16}$

The nurses are required to possess technical competencies, skills with tweezers, abilities with syringes, good communication, among other activities that grant them the legitimacy to develop care with the subjects in critical life situations. At the same time as care is described as necessary and accessible to all, the magazines show its complexity in the dying process, which even weakens the nursing professionals. The professionals are expected to develop integral and holistic care, singular care that accompanies the individualizing mode of nursing education. On these grounds, for the professionals to take care of other beings, they should know themselves. They need to take care of themselves, acknowledging potentials and putting them at the mercy of the job market and the social and health needs. ${ }^{20}$

Another aspect in the reports is the relation between nursing and work that is considered dirty, directly linked to the patients' body and its excrements.

“Maria de Cleide, Regina, Zilda, Neucilene, Edineia, Mary [...] They are 18 auxiliary nurses. They spend day and night at the patients' side, helping them to urinate and defecate, bathing, cleaning blood and vomiting, listening" 17:66

Nursing uses the senses to deliver care. In combination, the senses operate by helping to detect problems and plan care for the people affected by a disease. ${ }^{21}$ As observed, nursing work is linked to the body, to smell, hearing, sight and, sometimes, seems to be underrated in the discourse, as it involves the sexuality of the caregiver and the person receiving care. Dealing with the other person's sexuality represents a sensitive point in this scenario. Assisting and delivering the bed bath and dealing with excrements mobilizes the senses of the people delivering care, often causing insecurity and discomfort. ${ }^{22}$ Like the body, the object and instrument of Nursing care, sexuality is permeated by the wording of oppression with regard to sex. "Saying that sex is not repressed, that is, saying that no relation of oppression exists between sex and power is at risk of being but a paradox. [...] That would meet the entire economy, all of the discursive interests that sustain it". ${ }^{23: 14}$ In function of these cultural aspects related to the profession, Nursing work sometimes seems to be put to the background in the Brazilian media.

Nudity also appears as something shameful, and is directly related with sex, representing a taboo in terms of care. According to Barthes' reading of George Bataille, nudity is a plastic value linked to figuration and to what can only be represented at a distance, symbolically. In his work, Bataille explores what seems to be prohibited, questioning the value attributed to words, relating them with the context they are formulated in. The author discusses three hubs of meanings: noble hub, ignoble hub and low hub. In the first, there is superiority, words that refer to nobility, to free forms; the second contains the median words, related to the dark, hidden, conventions; finally, the low hub includes a set of meanings attributed to words like blood, mud, hate. This semantic hierarchy is related to the place these words are pronounced in, who pronounces them and how they influence the signification of the relationships. ${ }^{24}$

Therefore, the differences between how nursing and medicine appear in the media are highlighted. Although both professions work with the subjects' body, nursing seems to be in an inferior position, as it is not presented as the profession that dialogues and advises, but as the profession that does and, therefore, is located in the low hub in semantic terms, according to Bataille's proposal. ${ }^{24}$ This relation is relevant, departing from the premise that words and discourse represents the power relations, granting more or less visibility to what one wants to produce as true in the media. These differences can also be related with the discursive and social spaces both professions were constituted in and with the consolidation in terms of their economics and pro- 
fessional corporatism. In the reports, differently from what happens with medical professionals, no images appear of nursing professionals taking care of people who are dying or any other element remitting to the profession.

\section{Medicine: knowledge that educates, governs and prepares the subjects for death}

In the magazines, the physician stands at the center of the relationships. The physician is granted the right to advise on the best way to die. Renowned hospital authorities are invited to testify in the reports to grant legitimacy to the discourse and power to what is disseminated. The physicians who talk tend to be linked to intensive care services or are oncologists, perhaps because cancer is considered a disease that remits to a death sentence.

"In the decision not to postpone an inevitable death, what matters is the physician's technical assessment. Emotional factors cannot exert influence" ${ }^{25: 90}$

"My vital will should contain one single piece of information: the name of my trusted physician. He is the most indicated person to make decisions on my life and death. My physician will not allow that I' $m$ in pain and suffer for weeks if that does not grant me a dignified condition of survival". ${ }^{26: 102}$

The importance granted to the physician in communication media can be related to the historical constitution of Medicine and the power it gained on the subjects' bodies, to the extent that the physician decides on what is best for his patients from birth till death. The way this professional stands towards the dying subjects is noteworthy: paternalistic, justified by rational action. The physicians are expected to assume a posture based on scientific discourse. The physician acts as a pastor, who holds the truth and can advise anyone in search of a dignified death.

Historically, a medicalization process of health and vital processes is observed, made possible by the Cartesian logic that promotes the separation between reason and emotion, between the empirical and the scientific in modern thinking. This scenario favors the birth of clinical medicine as a profession of power over the bodies. ${ }^{15}$ The images the physicians appear in, linked to technology, equipped with what protects them as professionals and what makes them capable of controlling the unpredictable and acting on untimeliness are examples of this rationality that appears in the magazines. When medical opinions need to be presented, the artifacts turn to a dark background and the images remit to hospital technology. In the magazines, the professionals seem to be concerned with equipment and distant from ill people. A recurring element is the heart monitor with the lines of an electrocardiogram, relating life with the beating of the heart. Sight stands out in the images. It is considered fundamental for medical work: "There is a circumscribed look, a look bordering on touch and hearing, which only covers one of the sensory fields and only flourishes on visible surfaces, and a totally integrative look that dominates and establishes all perceptive experiences" ${ }^{15: 183}$ This conjuncture of elements contributes to achieve what the media intends to do: position, incite, summon, bring about emotions and convince. ${ }^{27}$

The physician's social status is very singular in the Western culture. This figure gained, especially as from the French revolution, the invention of hospital, the modernization and urbanization of Europe, physical and moral control over the bodies. When a physician talks, his image cannot be dissociated from a cultural system surrounding the profession, which defines the place of his power, granting him "the right to articulate it, claiming for himself the power to conjure up suffering and death". ${ }^{11: 57}$

The strength of the medical discourse is preponderant and cooperative with political and economic forms that govern lives. The physician questions, observes and, in addition, writes and describes, treats the disease as a collection of symptoms. The intervention takes place in the body, which can receive its practices. Through the technology and introduction of this apparatus at the hospital, Medicine gained power over life. This scenario granted the clinical field a new structure, in which the subject is a pathologically more observable fact than an ill person. ${ }^{15}$ The images in the reports of the physician linked to the device, not to the subject are not a coincidence. There is a retreat from the bodies, but an approach through a power that operates by convincing, by the discourse that is legitimized by the knowledge that determines what to do to maintain life and, when that is no longer possible, to let it take its natural course. In the magazines, the discourse is loaded by this historicity surrounding medicine.

"Part of us hopes for a physician who, in view of our weakness, says: 'Do not worry, we will fight with all of medicine's weapons'. In exchange, he only expects our complete obedience. Many do not even have the patience to explain the strategy and 
the collateral damage of the treatment, while others take offense when questions are raised." 28

"We train our physicians to be warriors or priests who deny death at all cost" ${ }^{18: 100}$

The physician acts as a protector of life. And who is entitled to decide on what is best, prescribing behaviors and attitudes to be taken. A posture of delivery is verified in the people called "patients". Patients who receive, listen and follow the orders of the person knowledgeable on the body. The family members also seem to be in a passive position towards the physician and the health services. The images of the family or caregivers awaiting information on patients hospitalized at Intensive Care Units appoint the physical distancing the hospital conjuncture imposes. Figure 1 shows two family members inside a waiting room.

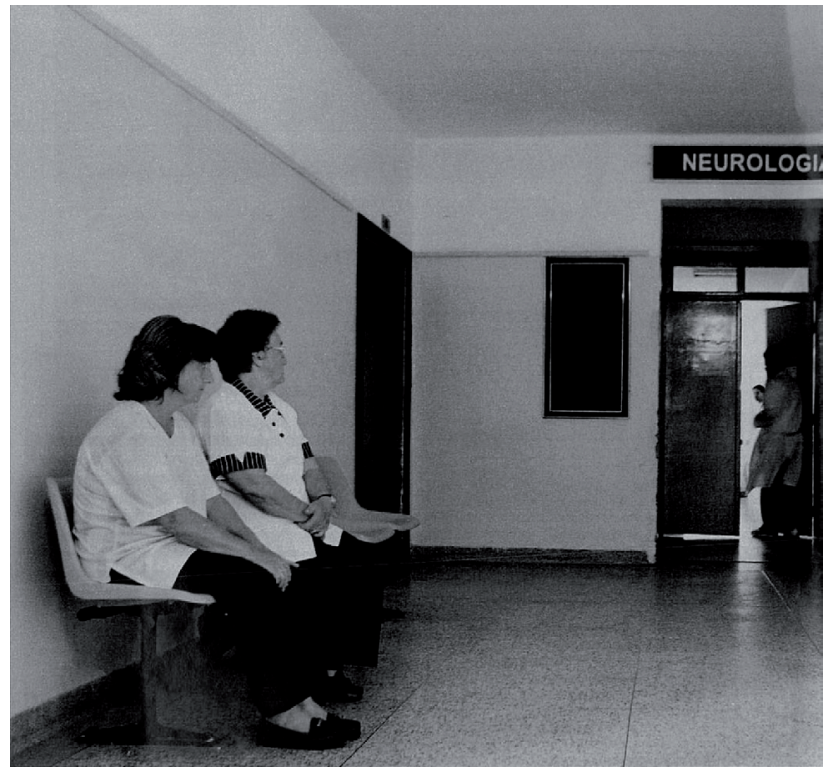

Source: Veja 2002 Sep. 04; p.88. Credits: Antônio Milena

\section{Figure 1 - Relatives at Intensive Care Unit}

Both are women, the predominant gender of hospital caregivers. They are sitting on hardly comfortable benches, lower than the professional who comes in, apparently in a hurry, without paying them further attention. The crossed hands, indicating waiting, and the intrigued and concerned look turned upwards towards the professional and care unit illustrate the situation of the people taking care of or accompanying a family member in most Brazilian hospitals. A posture indicating delivery and waiting. Waiting to receive, at any moment, information, a direction, a conduct.

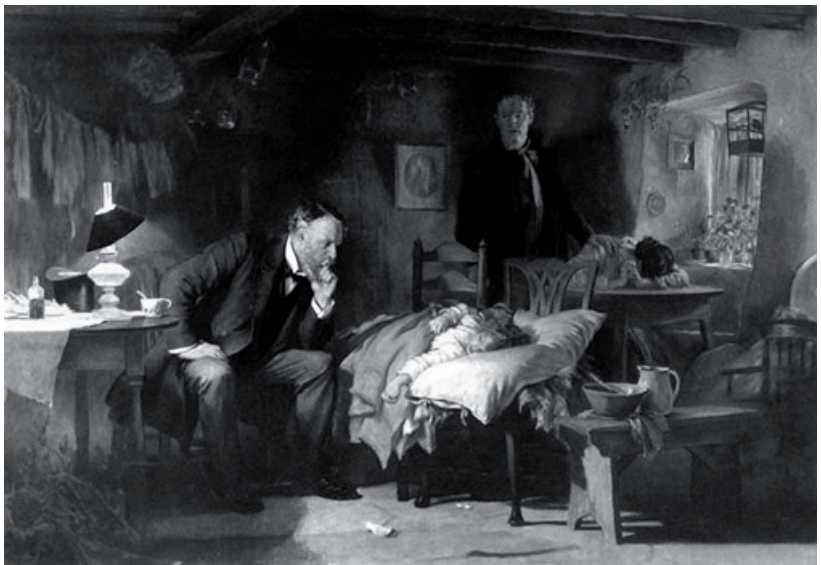

Source: www.fugesp.org.br

Figure 2 - The physician ${ }^{29}$

When considering the picture (Figure 2) by the painter Samuel Fildens, The physician, and observing one of the possible analyses of this work, ${ }^{29}$ the physician's role as the driver of subjects' life is approached and questioned. In the above image from 1891, the professional is prostrated in view of a child's terminality who, based on the arrangement of the objects in the picture, received intense investments in the attempt to avoid the end. The death scene is highlighted by the luminosity of the picture, as that is the event displayed. The way the physician observes the dead body seems to indicate the professional's suffering.

Some observations are added in this interlocution. The death represented in the picture takes place at home. The child's parents are in the background and do not seem to be a linking and communicating element between the caregiver and care receiver, which makes us associate the body with the distancing of relatives in the waiting room, as illustrated in figure 1. Both the picture and the figure of the relatives in the waiting room permit the analysis of the movements related to death in the past two centuries. Physical changes are appointed, as well as in the family's role and in the physician's function as the person who knows what should be done at the time of death.

If, in Fildens' picture, the reaction of the physician's sensitivity to the dead body is observed, the professionals' discourse in the magazines seems to reveal the transitiveness and extirpation of emotions at the time of death. Rationality and distancing are expected from the physicians. Medical knowledge seems to have appropriated itself of and taken refuge of death. The end of life turns into a tool that 
permits the invention of clinical medicine, favors its mastery over the bodies and arranges new organic and cultural practices surrounding the pathological classifications and burial rituals. ${ }^{15}$

\section{About another territory: the judicialization of the dying process}

The magazines appoint that the decision about the end of life is the most difficult to take. In that sense, the question is raised: the most difficult for whom? As a decision about the life, the body and the death of each, it seems to be a decision of the subject. Nevertheless, this seems to be a decision of medicine and law. To allow the subjects in Brazil to choose not to make therapeutic investments, the Federal Council of Medicine needed to intervene.

In countries where life-extending treatments can be limited or removed and where assisted suicide or euthanasia is permitted, these procedures are only permitted after medical assessment, requiring the elaboration of a vital will, preferably registered before a notary. ${ }^{30}$ This document gains validity based on the authorization of two core actors in these situations: the physician and the lawyer. A paper, the writing and the law. These elements are related when we discuss death and its developments. The following excerpts appoint who is authorized to teach and permit dying: they evidence the two professions that can indicate decisions about death.

"On August $26^{\text {th }}$ and $27^{\text {th }}$, the Federal Council of Medicine (CFM) organizes an event in São Paulo which can represent a landmark in the humanization not only of health, but of life: physicians and lawyers will discuss the creation of the vital will". ${ }^{31}$

"In a historical decision, the Federal Council of Medicine (CFM) has just enacted a determination to consecrate the patient's autonomy over his own destiny". ${ }^{26: 100}$

The judicialization crosses health and the constitution of new forms of dying in contemporary times, circulating in the magazines' discourse. The search for health care turned into an element of legal intervention when the subjects started to realize the cure perspective and the possibility of the physicians' intervention and saving possibilities. ${ }^{32}$ While, until the end of the $19^{\text {th }}$ century, justice was sought for land, homes, ownership of material goods, when clinical medicine developed, at the same time as technologies were introduced in hospitals, people started to identify themselves as subjects entitled to health. Due to the difficulties to get access to the services, the possibility to extend existence provokes legal disputes about the right to life and, today, about the right to die as well..$^{33}$

Justice plays a fundamental role in the determinations of truths in a certain age. Since the start of the $20^{\text {th }}$ century, especially as from the Second World War, when the notions of democracy were strengthened in the constitution of nations, the legal interventions at all levels of life increased. In the health context, in Brazil, the growing crossing of judicialization is identified, especially as from the 1980's, with the HIV/ AIDS epidemic and the rising incidence and prevalence rates of chronic illnesses, which culminated in legal claims to fund lengthy treatments, especially the most costly ones. ${ }^{33}$

In this context, the physician and the lawyer sometimes converge and at other times diverge on the decisions about the right to life and death. They converge in that both are the actors who authorize the access to health institutions and care in those cases when the demand exceeds the supply. They diverge when legal demands in favor of hospitalization, for example, cannot be absorbed. These conflicts result in ethical dilemmas for all stakeholders and in the trend towards the bureaucratization of decisions. Sometimes, there is an intense and time consuming formality of documents to authorize certain practices, like the validation of a vital will for example, which the medical part considers negative, while the legal part considers it as necessary.

Thus, it is verified that the ill persons interfere least in the practice surrounding their death - which is amenable to discourse and interventions from medical and legal knowledge. These instances operate by putting in practice what Foucault ${ }^{34}$ called social orthopedics, characterized as a form of power that plasters, modulates and produces social control through knowledge about the other and the prescription of behaviors, practices and habits that operate on the body and the soul of each, constituting biopolitical strategies of the State related to death.

\section{FINAL CONSIDERATIONS}

The media articulates the knowledge that governs the bodies in the end-of-life context. The knowledge visible on the pages of the magazines Época and Veja is related to medicine and law, and rarely to nursing.

The analyses revealed visibilities and sayings about death that mostly involve medical knowledge, marking the space this category occupies in the historical construction of knowledge and power in 
Western society. The physician is put forward as a pastor of this age, who advises, guides and indicates the routes to be followed in the attempt to produce death without suffering. The magazines appoint that the practices inscribed in the bodies of the subjects with life-threatening diseases should be sanctioned by medical knowledge. As observed, even when the subjects are called upon to decide on their death and the practices to be inscribed in their bodies, we are under medical recommendations. And if nothing can be done to cure, the family and nursing appear to take care. In this scenario, the media presents nursing as yet another element in the care process. Knowledge situated between the scientific and the family context. A profession linked to the body, but restricted to the technique. Thus, two types of health knowledge are introduced: medical knowledge, which modifies and prescribes conducts, and nursing knowledge, which takes care through action.

In the reports, the health professions are discussed to highlight medicine. This discourse does not converge with the palliative care philosophy, which appoints the multiprofessional team as one of the pillars of end-of-life care. In addition, the magazines seem to underline the legal area with a determinant role in the access to health services. A knowledge that legitimizes the health practices that organize life from birth till death.

\section{REFERENCES}

1. Marinho S, Arán M. As práticas de cuidado e a normalização das condutas: algumas considerações sobre a gestão sociomédica da "boa morte" em cuidados paliativos. Interface (Botucatu) [internet]. 2011 [cited 2014 Jun 08]; 15(36):7-20. Available from: http://dx.doi.org/10.1590/S1414-32832010005000039

2. Silva KS, Kruse MHL. In defense of society: the invention of palliative care and the production of subjectivities. Rev Esc Enferm USP [internet]. 2012 [cited 2013 Dec 08]; 46(2):460-5. Available from: http://dx.doi.org/10.1590/S0080-62342012000200026

3. Maciel MGS, Rodrigues LF, Naylor C, Bettega R, Barbosa SM, Burlá C, et al. Critérios de qualidade para os cuidados paliativos no Brasil. Rio de Janeiro (RJ): Diagraphic; 2009.

4. Brasil. Resolução n ${ }^{0} 1.995$, de 09 de agosto de 2012. Dispõe sobre as diretivas antecipadas de vontade dos pacientes. Diário Oficial da República Federativa do Brasil, 31 ago 2012. Seção 1.

5. Ribeiro RG, Kruse MHL. The woman body in review: the imperative of beauty. Texto Contexto Enferm [internet]. 2014 [cited 2014 Jun 06]; 23 (1): 101-8. Available from: http://dx.doi.org/10.1590/S010407072014000100012
6. Ministério da Saúde (BR). Secretaria executiva. Núcleo Técnico da Política Nacional de Humanização. Humaniza SUS: Humaniza SUS: Política Nacional de Humanização: a humanização como eixo norteador das práticas de atenção e gestão em todas as instâncias do SUS, Brasília, DF: Ministério da Saúde; 2004.

7. Ministério da Saúde (BR). Portaria n. 2.439/GM de 8 de dezembro de 2005: institui a política nacional de atenção oncológica. Diário Oficial da República Federativa do Brasil, 9 Dez 2005. Seção 1.

8. Ministério da Saúde (BR). Portaria n. 963, de 27 de maio de 2013. Redefine a Atenção Domiciliar no âmbito do Sistema Único de Saúde (SUS). Diário Oficial da República Federativa do Brasil, 29 Ago 2013, Seção 1.

9. Muhr T. Atlas. ti: Qualitative data analysis 7 [internet]. 2013 [cited 2013 Feb 22]. Available from: http:/ / www. atlasti.com/index.html

10. Foucault M. A ordem do discurso. $7^{\mathrm{a}}$ ed. São Paulo (SP): Loyola; 2003.

11. Foucault M. A arqueologia do saber. $7^{\mathrm{a}}$ ed. Rio de Janeiro (RJ): Forense Universitária; 2008.

12. Foucault M. Microfísica do poder. $2^{\mathrm{a}}$ ed. Rio de Janeiro (RJ): Graal; 2010.

13. Brasil. Lei $n^{\circ} 9.610$, de 19 de fevereiro de 1998. Altera, atualiza e consolida a legislação sobre direitos autorais e dá outras providências. Diário Oficial da República Federativa do Brasil, 20 fev 1998. Seção 1.

14. Schwengber MSV. Donas de si? : a educação de corpos grávidos no contexto da Pais \& Filhos [tese]. Porto Alegre (RS): Universidade Federal do Rio Grande do Sul, Programa de Pós-Graduação em Educação; 2006.

15. Foucault M. O nascimento da clinica. $6^{\mathrm{a}}$ ed. Rio de Janeiro (RJ): Forense Universitária; 2004.

16. Kruse MHL. Os poderes dos corpos frios-das coisas que se ensinam as enfermeiras [tese]. Porto Alegre (RS): Universidade Federal do Rio Grande do Sul, Programa de Pós-Graduação em Educação; 2003.

17. Brum E. A enfermaria entre a vida e a morte. Época [internet]. 2008 [cited 2013 jan 15]. Available from: http:/ / revistaepoca.globo.com/Revista/ Epoca/0,EMI10399-15257,00-A+ENFERMARIA+E NTRE+A+VIDA+E+A+MORTE.html

18. Souza O, Zakabi R. Em busca de um lugar sereno. Veja. 2005 nov; 92-100.

19. Pires D. A enfermagem enquanto disciplina, profissão e trabalho. Rev Bras Enferm [internet]. 2009 [cited 2014 Ago 25]; 62(5):739-44. Available from: http:/ / dx.doi. org/10.1590/S0034-71672009000500015

20. Boemer MR. Enfermagem e morte. In: Santos FS, Incontri D. A arte de morrer: visões plurais. Bragança Paulista (SP): Comenius; 2007. p. 188-95.

21. Araújo STC, Cameron LE, Oliveira LFD. O sentido olfato no cuidado de enfermagem hospitalar. Esc Anna Nery [internet]. 2011 [cited 2014 Jun 09]; 15(4):811-7. 
Available from: http://dx.doi.org/10.1590/S141481452011000400021

22. Silva JR, Lima PC, Santos RM, Trezza MCSF, Veríssimo RCS. Nudez do paciente sob a óptica de estudantes da área de Enfermagem Fundamental. Rev Bras Enferm [internet]. 2012 [cited 2013 Jun 12]; 65 (3):428-36. Available from: http://dx.doi.org/10.1590/S003471672012000300006

23. Foucault M. História da sexualidade 1: a vontade de saber. Rio de Janeiro (RJ): Graal; 2001.

24. Barthes R. O rumor da língua. São Paulo (SP): Martins Fontes; 2004.

25. Schelp D. Até onde prolongar a vida. Veja. 2002 set; 82-91.

26. Lopes AD, Cuminale N. Eu decido meu fim. Veja. 2012 set; 98-106.

27. Kellner D. A cultura da mídia. Bauru (SP): EDUSC; 2001.

28. Brum E. Você quer ser pessoa ou paciente. Época [internet]. 2012 [cited 2013 jan 15]. Available from: http:/ / revistaepoca.globo.com/Sociedade/elianebrum/noticia/2012/09/voce-quer-ser-pessoa-oupaciente.html

29. Alves R. O médico. $7^{\text {a }}$ ed. Campinas (SP): Papirus; 2002.

30. Lippman E. Testamento vital: o direito a dignidade. São Paulo (SP): Matrix; 2013.

31. Brum E. Testamento vital. Época [internet]. 2010 [cited 2013 jan.15]. Available from: http://revistaepoca. globo.com/Revista/Epoca/0,EMI154190-15230,00. html

32. Serres M. Hominescence. Paris (FR): Le Pommier; 2001.

33. Travassos DV. Judicialização da saúde e Sistema Único de Saúde: estudo de caso de três tribunais brasileiros [tese]. Belo Horizonte (MG): Universidade Federal de Minas Gerais, Programa de Pós-Graduação em Odontologia; 2012.

34. Foucault M. A verdade e as formas jurídicas. $3^{\mathrm{a}} \mathrm{ed}$. Rio de Janeiro (RJ): NAU; 2002. 